\title{
Differences in vertical and horizontal distribution of fish larvae and zooplankton, related to hydrography
}

\author{
Höffle, Hannes; Nash, Richard D.M.; Falkenhaug, Tone; Munk, Peter
}

Published in:

Marine Biology Research

Link to article, DOI:

10.1080/17451000.2013.765576

Publication date:

2013

Link back to DTU Orbit

Citation (APA):

Höffle, H., Nash, R. D. M., Falkenhaug, T., \& Munk, P. (2013). Differences in vertical and horizontal distribution of fish larvae and zooplankton, related to hydrography. Marine Biology Research, 9(7), 629-644.

https://doi.org/10.1080/17451000.2013.765576

\section{General rights}

Copyright and moral rights for the publications made accessible in the public portal are retained by the authors and/or other copyright owners and it is a condition of accessing publications that users recognise and abide by the legal requirements associated with these rights.

- Users may download and print one copy of any publication from the public portal for the purpose of private study or research.

- You may not further distribute the material or use it for any profit-making activity or commercial gain

- You may freely distribute the URL identifying the publication in the public portal

If you believe that this document breaches copyright please contact us providing details, and we will remove access to the work immediately and investigate your claim 
2 Differences in vertical and horizontal distribution of fish larvae and zooplankton, related to hydrography

5 HANNES HÖFFLE ${ }^{1 *}$, RICHARD D. M. NASH ${ }^{2}$, TONE FALKENHAUG ${ }^{3}$, \& PETER $6 \mathrm{MUNK}^{1}$

7

8

$9 \quad{ }^{1}$ DTU Aqua, National Institute of Aquatic Resources, Technical University of Denmark, 10 Charlottenlund, Denmark

$11 \quad{ }^{2}$ Institute of Marine Research Bergen, Norway

$12{ }^{3}$ Institute of Marine Research, Flødevigen, His, Norway

13

14 *Correspondence. Institute of Marine Research, PO Box 1870 Nordnes, 5817 Bergen,

15 Norway. hannes.hoeffle@imr.no

16

17 Running head: Vertical distribution of fish larvae in the North Sea.

18

19

20 


\section{Abstract}

23 Planktonic fish larvae have little influence on their horizontal distribution, while they are able

24 to control their vertical position in the water column. While prey and light are among the

25 factors with an apparent influence on the vertical distribution, the effects of other factors are

26 less clear. Notably, distributional differences between larvae of different fish species are

27 poorly understood. Information on the horizontal distribution of larvae of 27 species and the

28 vertical distribution of seven species of Gadidae, two Pleuronectidae and one Scopthalmidae,

29 was compiled from one survey in the northern North Sea. Horizontally, fish larvae aggregated near frontal structures, correlating with high densities of zooplankton. Increasing length and decreasing numbers indicated an origin in the western North Sea, followed by an eastward drift. Vertically, the different species exhibited similarities but also notable differences in their vertical distribution. Most gadoid species aggregated in the upper $(<40 \mathrm{~m})$ or middle water column (>40 m) during the day with an increase in abundance at shallower depths during the night, while all flatfish were distributed at greater depths under all light conditions. Hence, larvae differed in their distributional patterns, but the relative depth distributions among the species in the larval community generally remained constant.

Keywords: Fish larvae, Gadidae, Flatfish, Vertical distribution, North Sea 
42 Compared to current speeds the swimming ability of fish larvae is of minor importance, limiting their capability to influence their location by horizontal swimming. However, larvae can migrate vertically in the water column and so influence their horizontal transport, as current speed and direction often changes with depth (Fortier \& Leggett 1983; Sclafani et al. 1993).Vertical migration patterns of fish larvae can be broadly classified into three categories: i) type I migrations as upward movement at the beginning of night and downward movement at the beginning of day; ii) type II as the opposite (Neilson \& Perry 1990) and iii) a pattern of aggregation during the day and dispersal throughout the night (Gray 1998; Leis 1991; Olivar \& Sabatés 1997). Exogenous factors that influence the observed patterns are, for example, light, prey and predator distribution, as well as effects of temperature and salinity.

Individuals of given species and congeners often exhibit similar distribution patterns, regardless of the prevailing environmental conditions and form distinct assemblages in different depth strata (Gray \& Kingsford 2003; Olivar \& Sabatés 1997; Röpke 1993; Southward \& Barrett 1983). Size and consequently swimming ability, important for determining vertical distribution, changes throughout development and many species exhibit different vertical behaviours as the larvae develop (c. f. Table 1; Neilson \& Perry 1990). Lough and Potter (1993) observed the initiation of vertical migration in cod (Gadus morhua Linnaeus, 1758) and haddock (Melanogrammus aeglefinus Linnaeus, 1758) at standard lengths (SL) of 6-8 mm, and a firmly established type I migration at lengths greater than 9 mm SL. Smaller larvae and particularly those in poor condition may be more strongly influenced by buoyancy (Sclafani et al. 1993). However, even in their earliest stages, larvae will migrate if unfavourable conditions make it necessary (Grønkjær \& Wieland 1997). The influence of hydrography, in particular the position of the thermocline, is less clear. Some studies indicate a connection between larval distributions and the thermocline for certain taxa 

others show the same distributional patterns, both of single taxa and larval assemblages, irrespective of water column stratification (Gray 1998; Gray \& Kingsford 2003). Gray and Kingsford (2003) attributed their failure to find a relationship between distributions and the thermocline, to a combination of the gradual and ephemeral character of thermoclines in their study region and the lag-phase between the occurrence of hydrographic cues and the reaction of the larvae.

The influence of prey and predator distributions was pointed out by Pearre (1973) who, based on his studies of an arrow worm Sagitta elegans (Verrill, 1873), introduced the hungersatiation hypothesis. In this case vertical movements were related to the concurrent needs of feeding in the upper water column and hiding from visual predators at greater depths. The hypothesis was later applied to other planktonic organisms, including fish larvae (Pearre 2003). Visually hunting fish larvae can follow different strategies to satisfy these needs. They may rise in the water column at night, together with their zooplankton prey or may stay deeper and feed on vertically migrating prey (Lovetskaya 1953). Neilson and Perry (1990) suggested a feeding/avoidance window at dusk and dawn, when light conditions are sufficient for feeding but predators may still be at greater depths. The influence of light differs among species. Some species appear to select a specific isolume, which primarily governs their vertical distribution (Woodhead 1966). This has been suggested as the cause of aggregations during the day and diffuse distribution during the night when the primary cue is missing (Leis 1991). However, the effect of light is species specific as has been shown in concurrent laboratory studies (Catalán et al. 2011; Vollset et al. , in press), for example some species are shown to be adapted to low illumination (e.g. Downing \& Litvak 2001; Huse 1994; Yoon et al. 2010). 
91 Statistical models of the vertical distribution of different taxa have high predictive power with several interacting factors (Hernandez et al. 2009) and even when only using a single factor (Huebert et al. 2010). Control by a single factor is, however, rare. While prey abundance was one controlling factor for mesopelagic larvae in the Arabian Sea (Röpke 1993) and for Sardinella aurita (Valenciennes, 1847) in the northwestern Mediterranean Sea (Sabatés et al. 2008), the fish species were also limited by physical factors. The mesopelagic species were limited by a warm mixed layer above, and $S$. aurita most likely by the cool (ca. $15^{\circ} \mathrm{C}$ ) water below the pycnocline. The vertical distribution of larvae will influence horizontal transport, as different currents at different depths might lead to retention within or a displacement out of an area (Fortier \& Leggett 1982; Fortier \& Leggett 1983; Govoni \& Pietrafesa 1994) and several studies have shown aggregations of fish larvae in or near fronts (Kiørboe et al. 1988; Munk et al. 2002; Sabatés 1990). Likewise, food availability, the relationship between illumination and prey abundance, is correlated with the distribution of Baltic cod larvae (Grønkjær \& Wieland 1997).

Considering the apparent species differences in vertical distributions and migrations, a comparative approach might elucidate the factors that are of prime importance. Few studies have analysed the distributional patterns of a wide range of species in a comparative way (Frank et al. 1992; Gray 1996; Gray \& Kingsford 2003). Such an opportunity was available in the northern North Sea in 2010. The area east of the Shetland Isles is particularly species rich (Economou 1987) with an assemblage primarily consisting of Gadidae, Lotidae, Pleuronectidae and Scophthalmidae. In regard to abundance, the dominant species were whiting, ling (Molva molva, Linnaeus, 1758), Norway redfish (Sebastes viviparus, Krøyer, 1845) and Norway pout. It is an important spawning ground for several fish species which spawn in spring and we were able to describe both the major horizontal distributional patterns from transects of stations, and the vertical patterns by vertical stratified sampling over an 18 
hour period. In this contribution we focus on the distributional patterns of larval fish in relation to hydrography and in relation to the distribution of zooplankton $180-1000 \mu \mathrm{m}$. We hypothesize that relative to each other larvae of different species would retain their position in the water column.

\section{Materials and Methods}

\section{Field sampling}

Sampling was undertaken on the RV G.O. Sars (IMR, Bergen, Norway), between $25^{\text {th }}$ April and $5^{\text {th }}$ of May 2010, covering transects between 59.3 and $60.75^{\circ} \mathrm{N}$ (Figure 1). Five additional stations were sampled over the course of 18 hours in a 5 x 5 nautical miles (NM) sized area (designated 18h-station) east of the Shetland Islands.

Depth integrated samples were taken in double oblique hauls with a $76 \mathrm{~cm}$ diameter GULF VII high speed sampler (Nash et al. 1998), down to about $100 \mathrm{~m}$ depth. The sampler was equipped with a mechanical flow meter (General Oceanics, USA) in the mouth of the nose cone. A SCANMAR depth sensor was attached to the sampler and provided both depth and temperature measurements. For discrete depth sampling, a MOCNESS (Wiebe et al. 1985) with a $1 \mathrm{~m}^{2}$ opening and 4 nets (180 $\mu \mathrm{m}$ mesh) was deployed to ca. $100 \mathrm{~m}$ and then hauled obliquely to the surface, sampling the water column in strata with nets opening at about 100, 75, 40 and $20 \mathrm{~m}$. Flow meters and a CTD were attached to the MOCNESS and the filtered volume $\left(\mathrm{m}^{3}\right)$ estimated for each stratum. Larvae were sorted on board and were preserved in borax buffered $4 \%$ formaldehyde. Zooplankton was split in two fractions before preservation, using a Motoda splitting device. One half was preserved for identification and enumeration whilst the other half was size fractioned into $<1000 \mu \mathrm{m}, 1000-2000 \mu \mathrm{m}$ and $>2000 \mu \mathrm{m}$ 
samples. Each size fraction was dried at $60^{\circ} \mathrm{C}$ to constant weight in order to obtain dry weights, which were converted to milligrams dry weight per $\mathrm{m}^{3}\left(\mathrm{mg} \mathrm{DW} \mathrm{m}^{-3}\right)$ based on the volume of water filtered and to $\mathrm{g} \mathrm{DW} \mathrm{m}^{-2}$ based on filtered volume and sampled depth.

\section{Laboratory procedures}

The preserved larvae were cleaned of formalin under running water for 10-15 minutes. All larvae were then identified to the lowest taxonomic level, using either Russell (1976), Schmidt (1906) or Munk and Nielsen (2005). Standard length (SL; tip of the snout to the end of the notochord) was measured to the nearest $0.1 \mathrm{~mm}$ with an ocular micrometer. To correct for shrinking, live SL was calculated using the equation from Bolz and Lough (1984), after correcting for formalin shrinkage (Theilacker 1980).

\section{Data treatment and analysis}

Density anomaly $\left(\sigma_{t}\right)$ was calculated according to UN standards (Millero \& Poisson 1981) from temperature and salinity measured by CTD casts during the transects. The vertical profiles of calculated densities were interpolated on a regular grid $\left(0.5^{\circ} \times 5 \mathrm{~m}\right)$ with kriging in Surfer 8 (Golden Software 2002), while contour plots were constructed in Sigmaplot 12 (Systat Software 2011). The vertical profiles for the five hauls at the 18h-station are given as line graphs.

For each species in the depth integrated hauls, the catch was converted to nos. $\mathrm{m}^{-2}$ by dividing by the filtered volume and multiplying by the maximum sampler depth. Catch of larvae in the depth discrete hauls was converted to nos. $\mathrm{m}^{-3}$ by dividing by the filtered volume in a given 
stratum and these values were used in calculation of the depth of the centre of abundance $\left(\mathrm{Z}_{\mathrm{cm}}\right)$ from

$$
Z_{c m}=\frac{\sum D_{j} \times W D_{j} \times A_{j}}{\sum W D_{j} \times A_{j}}
$$

Where $D_{j}$ is the midpoint of stratum $j, W D_{j}$ the width of the individual stratum and $A_{j}$ is the abundance of the larvae. The depth of mass for zooplankton $<1000 \mu \mathrm{m}$ was calculated using the same formula, but replacing abundance with dry weight in $\mathrm{mg} \mathrm{m}^{-3}$. The relative abundance of larvae in each stratum was plotted as a \% of total abundance for day and night. $\mathrm{Z}_{\mathrm{cm}}$ was calculated and plotted for day, dusk, night and for single samples.

Only species for which the maximum abundance of larvae in a given stratum was above 2 per $100 \mathrm{~m}^{3}$ were used (10 out of 27 species; 37\%), as was the abundance of zooplankton $<1000$ $\mu \mathrm{m}$. The station sampled at 06:20 UTC was excluded from calculations for day distributions and $\mathrm{Z}_{\mathrm{cm}}$, as it was the first sample after sunrise and considered to be biased by the night distribution. Abundances per stratum were compared visually between species and between day and night. Similarly, $\mathrm{Z}_{\mathrm{cm}}$ was compared among species for day (19:14 UTC, 08:22 UTC), dusk (21:52 UTC) and night (23:56 UTC) as well as the relationship of species to the hydrography in the transects.

The depth of the centre of abundance was tested for significant differences between species, using one-factorial ANOVA for all species together and for Gadidae and flatfish separately. Data were tested beforehand with a Shapiro-Wilks and Levene’s test and were found to fulfil the requirements for normality and homogeneity of variance. Post hoc Tukey’s HSD was applied to discern between which species significant differences occurred. 


\section{Results}

\section{Hydrography}

185

186

Along both transects we observed a cool $\left(<7^{\circ} \mathrm{C}\right)$, low saline $(<34)$ surface layer over the Norwegian trench, extending to ca. $50 \mathrm{~m}$ depth (Figure 2), representing the Norwegian Coastal Current (NCC). Coldest temperatures occurred at ca. 30 m, while lowest salinities and densities were at about $10 \mathrm{~m}$ depth (Figures 2a, b). Correspondingly, $\sigma_{\mathrm{t}}$ was increasing with depth and ranged from $25.5 \mathrm{~kg} \mathrm{~m}^{-3}$ to $27 \mathrm{~kg} \mathrm{~m}^{-3}$. Beneath the NCC water, the temperature increased down to 200-300 m, while at greater depths temperatures fell below $7^{\circ} \mathrm{C}$ and $\sigma_{\mathrm{t}}$ rose to 27.6 in the deepest parts of the Norwegian trench. On the shallow plateau, between $1^{\circ} \mathrm{W}$ and $3^{\circ} \mathrm{E}$, temperature changed markedly with depth, while salinity was almost homogenous throughout the water column, except for the eastern margins. In the southern transect a thermocline at about $50 \mathrm{~m}$ was separating water of $>7^{\circ} \mathrm{C}$ and $\sigma_{\mathrm{t}}$ of $27.5 \mathrm{~kg} \mathrm{~m}^{-3}$ from cooler and denser water below. In the northern transect the warmer water reached down to a depth of $100 \mathrm{~m}$ and the thermocline was less strong. On the western margins of the southern transect water temperature increased rapidly between $0.5^{\circ} \mathrm{W}$ and $1^{\circ} \mathrm{W}$, while salinity decreased from about $1.7^{\circ} \mathrm{W}$ westwards. Together this led to the formation of a frontal structure. In the North, temperature increased more gradually, while salinity did not change. Overall the highest temperatures were measured at $>8^{\circ} \mathrm{C}$ on the western margins. Throughout the northern transect the surface water exhibited a $\sigma_{\mathrm{t}}$ of $<27.5 \mathrm{~kg} \mathrm{~m}^{-3}$ while on the western margin these lower densities reached down to a hundred metres.

The hydrography at the 18h-station exhibited little variability in time or depth (Figure 3). Salinity was relatively high and stable, only changing from 35.32 to 35.33 in the sampled water column of $120 \mathrm{~m}$. The temperature likewise varied little; it was about $8^{\circ} \mathrm{C}$ to $50 \mathrm{~m}$ and 
206 then declined continuously to $7.6^{\circ} \mathrm{C}$. Fluorescence peaked at $0.12 \mu \mathrm{g} \mathrm{L}{ }^{-1}$, but estimates varied during the period of investigation.

At the stations closest to the Norwegian trench the total zooplankton concentration in both transects ranged between $3.7 \mathrm{~g} \mathrm{DW} \mathrm{m}^{-2}$ and $5.0 \mathrm{~g} \mathrm{DW} \mathrm{m}^{-2}$. Peak zooplankton concentrations were found at the stations near $1^{\circ} \mathrm{E}, 30.5 \mathrm{~g} \mathrm{DW} \mathrm{m}^{-2}$ in the South and $38.7 \mathrm{~g} \mathrm{DW} \mathrm{m}^{-2}$ in the North. However, at these stations the distribution between size fractions differed. While at the northern station, the zooplankton biomass was nearly equally distributed between the three different size fractions (Table 1), at the southern station the bulk of the zooplankton (20.1 g DW $\mathrm{m}^{-2}$ ) was in the $1000-2000 \mu \mathrm{m}$ size fraction, while the zooplankton $<1000 \mu \mathrm{m}$ was at $7.1 \mathrm{~g} \mathrm{DW} \mathrm{m}^{-2}$ and the $>2000 \mu \mathrm{m}$ size fraction was at $3.2 \mathrm{~g} \mathrm{DW} \mathrm{m}^{-2}$. At the westernmost stations zooplankton concentrations were again lower, with $19.9 \mathrm{~g} \mathrm{DW} \mathrm{m}^{-2}$ in the southern and $11.7 \mathrm{~g} \mathrm{DW} \mathrm{m}^{-2}$ in the northern transect for all size fractions combined.

During the survey, a total of 2030 fish larvae of 27 species in 9 families were identified area of the Norwegian trench, abundances were mostly $<30 \mathrm{~m}^{-2}$ (Figures 2a, b). In this area there were no flatfish and there were only gadoid larvae close to the western slope of the trench. Over the shallow plateau abundances were mostly low $\left(<10 \mathrm{~m}^{-2}\right)$, however long rough dab (Hippoglossoides platessoides Fabricius, 1780) and Norway pout (Trisopterus esmarkii Nilsson, 1855) occurred at abundances of ca. $200 \mathrm{~m}^{-2}$ and $300 \mathrm{~m}^{-2}$, respectively. 
229 Both the stations with these high abundances were at the boundary of salinities between 35 and 35.2, where also sharp changes in $\sigma_{\mathrm{t}}$ and high concentrations of zooplankton $<1000 \mu \mathrm{m}$

231

232 (7.1 $\mathrm{g} \mathrm{DW} \mathrm{m}^{-2}$ and $5.1 \mathrm{~g} \mathrm{DW} \mathrm{m}^{-2}$ ) were observed. Along the northern transect larval abundance and species diversity increased from the western slope of the Norwegian trench westward to ca. $1^{\circ} \mathrm{E}$, up to a maximum abundance of $500 \mathrm{~m}^{-2}$ (Figure 2b), coinciding with peak zooplankton densities. Along both transects the dominant species was Norway pout, followed by whiting (Merlangius merlangus Linnaeus, 1758). Flatfish of the families Pleuronectidae and Scophthalmidae were more abundant and species rich at the northern transect than at the southern. Notably, Ammodytidae of 3 species were limited to the southern transect with only lesser sandeel (Ammodytes marinus Raitt, 1934) at $>10 \mathrm{~m}^{-2}$. Ling (Molva molva Linnaeus, 1758) was found in high abundance, $\left(33.3 \mathrm{~m}^{-2}\right)$, at one station of the northern transect, but did not occur elsewhere (Table 2a).

At the single location between the two transects whiting was almost twice as abundant as Norway pout, while other gadoids were much less abundant $\left(<20 \mathrm{~m}^{-2}\right)$ than either of these (Table 2c). Blue ling (Molva dipterygia Pennant, 1784) and northern rockling (Ciliata septentrionalis Collett, 1875) were found in abundances over $20 \mathrm{~m}^{-2}$. Flatfish were similarly species rich and abundant as in the northern transect. Long rough dab and brill (Scolphthalmus rhombus Linnaeus, 1758) were most abundant, with $25.2 \mathrm{~m}^{-2}$ and $18.6 \mathrm{~m}^{-2}$, respectively. Clupeidae, Argentinidae and Gobiidae occurred sporadically along the transects as well as at the 18h-station, in some hauls and in high numbers (Table 2).

\section{Vertical distribution - 18 hours station}

Changes in zooplankton distribution between day and night varied between the size fractions. While the distribution of zooplankton $<1000 \mu \mathrm{m}$ varied only little (Figures 3b, c and 4) and 
being most abundant in the two topmost strata (>30\% each), coincided positively with the level of fluorescence. The larger size fractions exhibited stronger differences (Figures 3b, c), particularly the 1000 - $2000 \mu \mathrm{m}$ fraction which was proportionally most abundant in the 0 $20 \mathrm{~m}$ stratum during the day and almost homogenously distributed during the night. The trend towards a larger proportion in the deep strata during the night was common for all size fractions and was reflected in the depth of the mass of the small zooplankton which was relatively stable at around 40 m with noticeable but small deviations at night (Fig. 6) and when incorporating the station at 06:20 UTC (Fig. 7).

Seven gadoids and three flatfish species occurred in sufficient numbers to examine their vertical distribution. Cod was absent from the sample taken at dusk, otherwise all species occurred in all hauls. One group of gadoid larvae, consisting of cod (Gadus morhua), haddock (Melanogrammus aeglefinus), whiting and pollock (Pollachius pollachius Linnaeus, 1758), was distributed in the upper water column $(0-40 \mathrm{~m})$ during day and night. Cod (62\%) and haddock (52\%) were most abundant at $0-20 \mathrm{~m}$ during the day and at $20-40 \mathrm{~m}$ at night, with $100 \%$ and 69\% respectively (Figures 4a, b). For whiting (Figure 4c) and pollock (Figure 4d) the change between these strata was reversed, as their abundance increased by 32 and 38 percent at 0 - $20 \mathrm{~m}$ during the night. While cod was never found below $40 \mathrm{~m}$ depth, the other species occurred in the deeper strata and ascended to shallower depths at night, $Z_{\mathrm{cm}}$ decreased accordingly (Figures 6a, 7a).

Saithe (Pollachius virens Linnaeus, 1758) and the two Trisopterus species (Figures 4e, g) were distributed in the strata below $40 \mathrm{~m}$ during the day. During the night saithe and poor cod (Trisopterus minutus Linnaeus, 1758) were most common in the upper water column, while $53 \%$ of Norway pout larvae remained at $75-100 \mathrm{~m}$ depth. 
In daylight all three flatfish species, witch (Glyptocephalus cynoglossus Linnaeus, 1758), brill and long rough dab were most abundant at 40 - $75 \mathrm{~m}$ depth (Figure 5), varying between 45\% for witch and 57\% for brill. During the night, witch and long rough dab were most abundant in the upper water column, peaking with $47 \%$ at $0-20 \mathrm{~m}$ and $77 \%$ at $20-40 \mathrm{~m}$, respectively. Brill remained most abundant at $40-75 \mathrm{~m}$ depth.

Except for brill, most larvae fell into a size range between 3 and 9 mm (Figs 8 - 10), with larger larvae occurring at low numbers. Brill was much more common at standard lengths of 2 - $3 \mathrm{~mm}$ than other species, while no brill larvae were longer than $5 \mathrm{~mm}$. Even such small larvae exhibited substantial changes in their distribution across depth strata (Figure 10), indicating that they were capable of controlling their position in the water column. With increasing standard length, whiting exhibited a tendency to be proportionally more common in the 0 - 20 m stratum, which was particularly noticeable at night (Figure 8). Norway pout, the other gadoids found over a wide size range, did not exhibit such a trend and between 4 and $7 \mathrm{~mm}$ length exhibited a reversed trend of a larger proportion in the $20-40 \mathrm{~m}$ stratum at a small size, while the larger larvae were in the deepest stratum at night (Figure 9). Larvae above $9 \mathrm{~mm}$ appeared to aggregate in one or the other strata, depending on species and prevailing light conditions.

When testing the depth of the centre of mass for difference between species, results were only significant within a single family, Gadidae $\left(\mathrm{F}_{6}=2.5\right.$; $\left.\mathrm{p}=0.047\right)$, but not for the group of flatfish $\left(F_{2}=0.2 ; p=0.82\right)$ or in an analysis of all species together $\left(F_{9}=1.8 ; p=0.1\right)$. The pattern in change of $Z_{\mathrm{cm}}$, between different light conditions was similar for most species (Figures 6, 7). $\mathrm{Z}_{\mathrm{cm}}$ decreased at night, except for cod, Norway pout and brill. While cod was found at greater depth during the night, Norway pout and brill had already ascended between day and dusk. 
301 Our study provides evidence for type I vertical migrations in the species examined, except for cod (Gadus morhua). However, in regard to timing, the migration patterns were not identical, as Norway pout (Trisopterus esmarkii) and Brill (Scophthalmus rhombus) ascended earlier and pollock (Pollachius pollachius) continued to rise until the early morning. With the exception of the two Trisopterus species the centre of abundance of all species was within the 20 - 40 m stratum either at dusk or during the night. In contrast to previous studies (Gray 1996; Olivar \& Sabatés 1997) we observed distinct assemblages in the upper and lower parts of the water column only during the day.

Our hydrographic observations are in accordance with findings described for the FeieShetland transect, reported by Hackett (1981). Hydrographic fronts were apparent at the western and eastern margins of the transects. Larval abundances and zooplankton concentrations were highest in the vicinity of these fronts which might imply that the frontal processes aggregate the zoo- and ichthyoplankton (Olson et al. 1994; Olson \& Backus 1985). Larval drift and dispersion from spawning grounds around the Shetland Isles is indicated by the general decline in larval abundance and diversity in parallel with an increase in larval mean lengths from these areas towards the East. Similar patterns have been suggested for Norway pout in other studies (Lambert et al. 2009; Nash et al. 2012).

In accordance with an east-west size gradient, the smallest average standard lengths were measured at the westerly positioned 18h-station. Cod and haddock (Melanogrammus aeglefinus) larvae were in the 6 - 8 mm size range in which Lough and Potter (1993) have observed the first appearance of vertical migrations. While our observations of cod larvae contain a high level of uncertainty, due to the low number of cod larvae in the samples, the distribution appears similar to earlier studies. The lack of cod larvae below $40 \mathrm{~m}$ is in 
accordance with other observation of early cod larvae confined to the waters above the thermocline (Grønkjær et al. 1997; Grønkjær \& Wieland 1997; Huwer et al. 2011; Lough \& Potter 1993). Our observations of Type II distributions in cod larvae were described earlier for both the Atlantic and the Pacific cod (Gadus macrocephalus Tilesius, 1810) (Boehlert et al. 1985; Munk , in press). The depth distributions found for haddock, whiting, pollock, Norway pout, witch (Glyptocephalus cynoglossus) and long rough dab (Hippoglossoides platessoides) were similar to the findings of Economou (1987). The propensity for large whiting larvae to occur shallower at night may be explained by their greater ability to rise quickly. This is supported by the increasing proportion of smaller larvae in the $20-40 \mathrm{~m}$ stratum. Apparently all whiting larvae were rising through the water column but the larger larvae were rising more rapidly. In comparison, Norway pout showed a different trend and generally less distinct differences between day and night. Saithe exhibited less variation in $\mathrm{Z}_{\mathrm{cm}}$ in earlier studies (Munk, in press). Poor cod (Trisopterus minutus) was found shallower than in the present study (Olivar \& Sabatés 1997). During the day Frank et al. (1992) found a shallower distribution of witch and long rough dab than in this study. However the bottom depth in their study was at $45 \mathrm{~m}$, which may have restricted the depth distribution. The distribution of brill appears not to be described in the literature. In many ways it resembled the distribution of Norway pout, concerning the particularly deep $\mathrm{Z}_{\mathrm{cm}}$ and the timing of the ascent. However the extent of the vertical migration was greater, covering $43 \mathrm{~m}$. Notably, brill larvae, which were on average smaller than those of other species, exhibited the largest difference in $\mathrm{Z}_{\mathrm{cm}}$ between day and night, suggesting that already at this small size brill larvae were capable of controlling their position in the water column. The overall tendency of large larvae to aggregate may reflect the developing patchiness in the distribution of older larvae (Hewitt 1981; Matsuura \& Hewitt 1995). However, the low number of larvae above 9 mm SL resulted in a great deal of uncertainty concerning diel shifts in distribution. 
349 Thermoclines have been described to lead either to larval aggregation (Lough \& Potter 1993;

350 Sabatés et al. 2008) or serve as a boundary for their migrations (Olivar \& Sabatés 1997;

351 Röpke 1993). Other studies found no apparent influence of thermoclines on larval vertical

352 distribution and migration patterns (Conway et al. 1997; Gray \& Kingsford 2003). The weak

353 stratification resulting in a weak thermocline observed at the 18-hours station is similar to

354 conditions in the studies of Gray and Kingsford (2003) and this might be the cause of the

355 apparent weak influence of the thermocline in both studies.

356 The aggregation in the 20 - $40 \mathrm{~m}$ stratum during the night suggests a support for the hypothesis that a hungry population would ascend just far enough to find sufficient food (Pearre 2003). The zooplankton that could be quantitatively sampled with the available equipment was generally too large to be potential prey for all but the largest fish larvae. Even though the small-sized copepods and nauplii are under-sampled by the $180 \mu \mathrm{m}$ mesh, we consider the distribution of the $<1000 \mu \mathrm{m}$ size fraction to reflect the distribution of smaller zooplankton. The smallest size fraction was concentrated in the upper water column which would be consistent with the aggregation of nauplii of most copepod species above the thermocline, which was observed in an earlier study (Krause \& Trahms 1982).

Gadoid larvae in the observed size range primarily feed on Calanus finmarchicus (Gunnerus, 1770) eggs and copepod nauplii (Economou 1991) and require about $36 \% \mathrm{~d}^{-1}$ of their own body mass (Jones 1973). For a larva of $6 \mathrm{~mm}$ standard length this would mean a requirement between $68 \mu \mathrm{g}$ for saithe and $125 \mu \mathrm{g}$ for cod (calculated following Economou 1987). Assuming a swimming speed and a reaction distance of one body length as well as proportions between $C$. finmarchicus eggs and nauplii and between nauplii stages as in Economou (1987) and Fransz et al. (1998) the corresponding number of food particles would be $3260 \mathrm{~m}^{-3}$ and $5973 \mathrm{~m}^{-3}$, respectively. In May such numbers are not unrealistic in the area 373 (Economou 1987) and would be well within the 27.6\% loss of biomass due to the mesh size 
used (interpolated from table III in Gallienne \& Robins 2001) However, zooplankton concentration in deeper strata should still have been sufficient to fulfil food requirements, which may explain why $\mathrm{Z}_{\mathrm{cm}}$ of Norway pout were not found any shallower than $51 \mathrm{~m}$ (equation from Economou 1987; based on: Jones 1973; Laurence 1985). The deepest $Z_{c m}$ observed after the apparent feeding period, could be due to larvae resting in deeper, cooler water to save energy and avoid visual predators (Brett 1971) or less buoyancy due to a full stomach (Sclafani et al. 1993).

In conclusion, whilst the general observation that most of the larvae occur at depths with high concentrations of zooplankton suggests a strong influence from the distribution of potential prey, the general vertical displacement of the mean depth indicates that other environmental factors might set a species-specific ‘background-depth’ of distribution. Therefore the physical water column structure might be the key factor determining the distribution of fish larvae, rather than the prey distributions. As suggested by Sclafani (1993), the neutral buoyancy of fish larvae is influenced by their condition. Further developed or better fed larvae, may be deeper in the water column, due to higher specific weight. As the species differ in the proportion of tissue types, the depth of neutral buoyancy may be different even when the larvae are in the same condition. We find that the comparative approach used in the present study has the potential for a new insight into the drivers behind vertical distribution patterns, and we suggest that further comparative community studies are undertaken.

\section{Acknowledgements}

The authors are grateful to the crew of the RV G.O. Sars (IMR, Norway) for undertaking the sampling and members of the IMR Plankton group for assistance with all aspects of the sampling at sea. The authors acknowledge Laura Rey at IMR, Bergen for her expertise in 
398 identifying fish larvae and all the other staff in the institute, for the support they provide to 399 guest scientists. We also thank the subject editor and two anonymous reviewers for their 400 constructive comments to the earlier submitted drafts of this work. The basic support for this 401 sampling programme was provided by the IMR North Sea programme. Hannes Höffle was 402 partially financed by the Danish national project SUNFISH (=SUstaiNable FISHeries, 403 climate change and the North Sea ecosystem).

404

405 


\section{References}

407 Boehlert GW, Gadomski DM, Mundy BC. 1985. Vertical distribution of ichthyoplankton off the Oregon coast in Spring and Summer months. Fishery Bulletin (Washington D C)

409 83:611-621.

410

411

412

Bolz GR, Lough RG. 1984. Growth of Larval Atlantic Cod, Gadus morhua, and Haddock, Melanogrammus aeglefinus, on Georges Bank Spring, 1981. Fishery Bulletin (Washington D C) 81:827-836.

Brett JR. 1971. Energetic Responses of Salmon to Temperature - Study of Some Thermal Relations in Physiology and Freshwater Ecology of Sockeye Salmon (Oncorhynchus nerka). American Zoologist 11:99-113.

Catalán I, Vollset K, Morales-Nin B, Folkvord A. 2011. The effect of temperature gradients and stomach fullness on the vertical distribution of larval herring in experimental columns. Journal of Experimental Marine Biology and Ecology 404:26-32.

Conway DVP, Coombs SH, Smith C. 1997. Vertical distribution of fish eggs and larvae in the Irish Sea and southern North Sea. Ices Journal of Marine Science 54:136-147.

Downing G, Litvak MK. 2001. The effect of light intensity and spectrum on the incidence of first feeding by larval haddock. Journal of Fish Biology 59:1566-1578.

Economou AN. 1991. Food and feeding ecology of five gadoid larvae in the northern North Sea. Journal du Conseil 47:339-351. 
425 Economou AN. 1987. Ecology of survival in some gadoid Larvae of the Northern North Sea.

426 Environmental Biology of Fishes 19:241-260.

427 Fortier L, Leggett WC. 1982. Fickian Transport and the Dispersal of Fish Larvae in Estuaries. 428 Canadian Journal of Fisheries and Aquatic Sciences 39:1150-1163.

429 Fortier L, Leggett WC. 1983. Vertical Migrations and Transport of Larval Fish in a Partially $430 \quad$ Mixed Estuary. Canadian Journal of Fisheries and Aquatic Sciences 40:1543-1555.

431

432

Frank KT, Loder JW, Carscadden JE, Leggett WC, Taggart CT. 1992. Larval Flatfish Distributions and Drift on the Southern Grand Bank. Canadian Journal of Fisheries and Aquatic Sciences 49:467-483.

Fransz HG, Gonzalez SR, Steeneken SF. 1998. Metazoan plankton and the structure of the plankton community in the stratified North Sea. Marine Ecology Progress Series 175:191200.

Gallienne CP, Robins DB. 2001. Is Oithona the most important copepod in the world's oceans? Journal of Plankton Research 23:1421-1432.

Golden Software. 2002. Surfer. Version 8.00. Golden, CO: Golden Software, Inc. Computer Program.

Govoni JJ, Pietrafesa LJ. 1994. Eulerian views of layered water currents, vertical distribution of some larval fishes, and inferred advective transport over the continental shelf off North Carolina, USA, in winter. Fisheries Oceanography 3:120-132. 
444 Gray CA. 1996. Do thermoclines explain the vertical distributions of larval fishes in the 445 dynamic coastal waters of south-eastern Australia? Marine and Freshwater Research $446 \quad 47: 183-190$.

447 Gray CA. 1998. Diel changes in vertical distributions of larval fishes in unstratified coastal 448 waters off southeastern Australia. Journal of Plankton Research 20:1539-1552.

449 Gray CA, Kingsford MJ. 2003. Variability in thermocline depth and strength, and 450 relationships with vertical distributions of fish larvae and mesozooplankton in dynamic $451 \quad$ coastal waters. Marine Ecology Progress Series 247:211-224.

452 Grønkjær P, Clemmesen C, St.John M. 1997. Nutritional condition and vertical distribution 453 of Baltic cod larvae. Journal of Fish Biology 51:91-352.

454 Grønkjær P, Wieland K. 1997. Ontogenetic and environmental effects on vertical distribution 455 of cod larvae in the Bornholm Basin, Baltic Sea. Marine Ecology Progress Series 154:91$456 \quad 105$.

457 Hackett B. 1981. The Feie-Shetland section: a hydrographic atlas. Report No. 3/81. 20 pages 458 and figures.

459 Hernandez FJ, Hare JA, Fey DP. 2009. Evaluating diel, ontogenetic and environmental 460 effects on larval fish vertical distribution using Generalized Additive Models for Location, $461 \quad$ Scale and Shape. Fisheries Oceanography 18:224-236. 
Hewitt R. 1981. The value of pattern in the distribution of young fish. Rapports et ProcesVerbaux des Reunions Conseil International pour l'Exploration de la Mer 178:229-236.

Huebert KB, Sponaugle S, Cowen RK. 2010. Predicting the vertical distributions of reef fish larvae in the Straits of Florida from environmental factors. Canadian Journal of Fisheries and Aquatic Sciences 67:1755-1767.

Huse I. 1994. Feeding at different illumination levels in larvae of three marine teleost species: Cod, Gadus morhua L., plaice, Pleuronectes platessa L., and turbot, Scophthalmus maximus (L.). Aquaculture and Fisheries Management 25:687-695.

Huwer B, Clemmesen C, Gronkjaer P, Koster FW. 2011. Vertical distribution and growth performance of Baltic cod larvae - Field evidence for starvation-induced recruitment regulation during the larval stage? Progress in Oceanography 91:382-396.

Jones R. 1973. Density dependent regulation of the numbers of cod and haddock. Rapports et Proces-Verbaux des Reunions Conseil International pour l'Exploration de la Mer 164:156173.

Kiørboe T, Munk P, Richardson K, Christensen V, Paulsen H. 1988. Plankton Dynamics and Larval Herring Growth, Drift and Survival in A Frontal Area. Marine Ecology Progress Series 44:205-219.

Krause M, Trahms J. 1982. Vertical-Distribution of Copepods (All Developmental Stages) and Other Zooplankton During Spring Bloom in the Fladen Ground Area of the North-Sea. Netherlands Journal of Sea Research 16:217-230. 
Lambert G, Nielsen J, Larsen LI, Sparholt H. 2009. Maturity and growth population dynamics of Norway pout (Trisopterus esmarkii) in the North Sea, Skagerrak, and Kattegat. Ices Journal of Marine Science 66:1899-1914.

Laurence GC. 1985. A report on the development of stochastic models of food limited growth and survival of cod and haddock larvae on Georges Bank. NOAA Technical Memorandum, Report No. NMFS-F/NEC-36, p 83-150.

Leis JM. 1991. Vertical distribution of Fish Larvae in the Great Barrier Reef Lagoon, Australia. Marine Biology 109:157-166.

Lough RG, Caldarone EM, Rotunno TK, Broughton EA, Burns BR, Buckley LJ. 1996. Vertical distribution of cod and haddock eggs and larvae, feeding and condition in stratified and mixed waters on southern Georges Bank, May 1992. Deep-Sea Research Part Ii-Topical Studies in Oceanography 43:1875-1904.

Lough RG, Potter DC. 1993. Vertical distribution patterns and diel migrations of larval and juvenile haddock Melanogrammus aeglefinus and Atlantic cod Gadus morhua on Georges Bank. Fishery Bulletin 91:281-303.

Lovetskaya AA. 1953. Distribution and behavior of the Caspian Sea sprat. Fisheries Industry 12:29-35.

Matsuura Y, Hewitt R. 1995. Changes in the Spatial Patchiness of Pacific Mackerel, Scomber-Japonicus, Larvae with Increasing Age and Size. Fishery Bulletin 93:172-178. 
501

502

503

504

505

506

507

508

509

510

511

512

513

514

515

516

517

518

Millero FJ, Poisson A. 1981. International One-Atmosphere Equation of State of Seawater. Deep-Sea Research Part A-Oceanographic Research Papers 28:625-629.

Munk P. in press. Fish larvae at fronts: horizontal and vertical distributions of gadoid fish larvae across a frontal zone at the Norwegian Trench. Deep-Sea Research Part Ii-Topical Studies in Oceanography

Munk P, Nielsen J. 2005. Eggs and Larvae of North Sea Fishes. Frederiksberg: Biofolia. 224pages.

Munk P, Wright PJ, Pihl NJ. 2002. Distribution of the early larval stages of cod, plaice and lesser sandeel across haline fronts in the North Sea. Estuarine Coastal and Shelf Science 55:139-149.

Nash RDM, Dickey-Collas M, Milligan SP. 1998. Descriptions of the Gulf VII/PRO-NET and MAFF/Guildline unencased high-speed plankton samplers. Journal of Plankton Research 20:1915-1926.

Nash RDM, Wright P, Matejusova I, Dimetrov S, O'Sullivan M, Augley J, Höffle H. 2012. Spawning location of Norway pout (Trisopterus esmarkii Nilsson) in the North Sea. Ices Journal of Marine Science 69:1338-1346.

Neilson JD, Perry RI. 1990. Diel Vertical Migrations of Marine Fishes - An Obligate Or Facultative Process. Advances in Marine Biology 26:115-168. 
519

520

521

522

523

524

525

526

527

528

529

530

531

532

533

534

535

536

Olivar MP, Sabatés A. 1997. Vertical distribution of fish larvae in the north-west Mediterranean Sea in spring. Marine Biology 129:289-300.

Olson DB, Backus RH. 1985. The Concentrating of Organisms at Fronts: A cold-water Fish and a warm-core Gulf Stream ring. Journal of Marine Research 43:113-137.

Olson DB, Hitchcock GL, Manano A, Ashjian CJ, Peng G, Nero RW, Podesta GP. 1994. Life on the edge: marine life and fronts. Oceanography 7:52-60.

Pearre S. 1973. Vertical Migration and Feeding in Sagitta elegans Verrill. Ecology 54:300314.

Pearre S. 2003. Eat and run? The hunger/satiation hypothesis in vertical migration: history, evidence and consequences. Biological Reviews 78:1-79.

Röpke A. 1993. Do larvae of mesopelagic fishes in the Arabian Sea adjust their vertical distribution to physical and biological gradients? Marine Ecology Progress Series 101:223-235.

Russell FS. 1976. The Eggs and Planktonic Stages of British Marine Fishes. London: Academic Press. 524 pages.

Sabatés A. 1990. Changes in the Heterogeneity of Mesoscale Distribution Patterns of Larval Fish Associated with A Shallow Coastal Haline Front. Estuarine, Coastal and Shelf Science 30:131-140. 
Sabatés A, Zaragoza N, Grau C, Salat J. 2008. Vertical distribution of early developmental stages in two coexisting clupeoid species, Sardinella aurita and Engraulis encrasicolus. Marine Ecology Progress Series 364:169-180.

Schmidt J. 1906. The pelagic post-larval stages of the Atlantic species of Gadus Part I. Bianco Lunos Bogtrykkeri, Report No. Bind I Nr. 4.77 pages.

Sclafani M, Taggart CT, Thompson KR. 1993. Condition, Buoyancy and the Distribution of Larval Fish - Implications for Vertical Migration and Retention. Journal of Plankton Research 15:413-435.

Southward AJ, Barrett RL. 1983. Observations on the Vertical distribution of zooplankton, Including post-larval teleosts, off Plymouth in the presence of a thermocline and a chlorophyll dense layer. Journal of Plankton Research 5:599-618.

Systat Software I. 2011. SigmaPlot for Windows. Version 12.0. Computer program.

Theilacker GH. 1980. Changes in Body Measurements of Larval Northern Anchovy, Engraulis mordax, and Other Fishes Due to Handling and Preservation. Fishery Bulletin 78:685-692.

Vollset KW, Catalán I, Fiksen O, Folkvord A. in press. Effect of food deprivation on the distribution of larval and early juvenile cod in experimental vertical temperature and light gradients. Marine Ecology Progress Series 
555 Wiebe PH, Morton AW, Bradley AM, Backus RH, Craddock JE, Barber V, Cowles TJ, Flierl 556 GR. 1985. New developments in the MOCNESS, an apparatus for sampling zooplankton 557 and micronekton. Marine Biology 87:313-323.

558 Woodhead PMJ. 1966. The behaviour of fish in relation to light in the sea. Oceanography and $559 \quad$ Marine Biology Annual Review 4:337-403.

560 Yoon HS, Hwang JH, Choi SD. 2010. Effect of light intensity on first feeding of the chub 561 mackerel Scomber japonicus larvae. Animal Cells and Systems 14:125-128.

562

563 
Table 1: Zooplankton densities (g DW $\mathrm{m}^{-2}$ ), per size fraction for all sampled stations, based on GULF VII hauls. The highest abundances along transects were found at the stations at ca. $1^{\circ} \mathrm{E}$. Proportions differed between transects. While the biomass in the southern transect was dominated by the 1000-2000 $\mu \mathrm{m}$ size fraction, proportions in the northern transect and at the 18h-station were more even between the two smaller size the biomass.

\begin{tabular}{|c|c|c|c|c|c|c|}
\hline \multirow[b]{2}{*}{ Transect } & \multirow[b]{2}{*}{ Station No. } & \multirow[b]{2}{*}{ Longitude } & \multicolumn{4}{|c|}{ Density per size fraction $\left({\left.\mathrm{g} \mathrm{DW} \mathrm{m}^{-2}\right)}\right.$} \\
\hline & & & $180-1000 \mu \mathrm{m}$ & $1000-2000 \mu \mathrm{m}$ & $>2000 \mu \mathrm{m}$ & Total \\
\hline \multirow[t]{5}{*}{$60.75^{\circ} \mathrm{N}$} & 423 & $0.47^{\circ} \mathrm{W}$ & 7.0 & 4.6 & 0.1 & 11.7 \\
\hline & 429 & $0.91^{\circ} \mathrm{E}$ & 19.5 & 17.3 & 1.9 & 38.7 \\
\hline & 433 & $2.60^{\circ} \mathrm{E}$ & 2.1 & 11.6 & 0.2 & 13.9 \\
\hline & 437 & $3.28^{\circ} \mathrm{E}$ & 0.9 & 2.7 & 0.2 & 3.7 \\
\hline & 444 & $4.45^{\circ} \mathrm{E}$ & 1.7 & 2.0 & 0.0 & 3.7 \\
\hline \multirow[t]{5}{*}{$59.3^{\circ} \mathrm{N}$} & 388 & $4.83^{\circ} \mathrm{E}$ & 3.1 & 1.3 & 0.6 & 5.0 \\
\hline & 402 & $2.52^{\circ} \mathrm{E}$ & 0.7 & 2.8 & 0.4 & 3.9 \\
\hline & 406 & $1.32^{\circ} \mathrm{E}$ & 7.2 & 20.1 & 3.2 & 30.5 \\
\hline & 410 & $0.00^{\circ} \mathrm{E}$ & 0.7 & 5.8 & 0.1 & 6.6 \\
\hline & 414 & $1.32^{\circ} \mathrm{W}$ & 5.1 & 10.1 & 4.7 & 19.9 \\
\hline \multirow[t]{5}{*}{ 18h-St. } & 418 & $0.61^{\circ} \mathrm{W}$ & 5.0 & 4.6 & 0.9 & 10.5 \\
\hline & 419 & $0.65^{\circ} \mathrm{W}$ & 4.6 & 8.0 & 0.4 & 12.9 \\
\hline & 420 & $0.68^{\circ} \mathrm{W}$ & 4.8 & 5.8 & 0.2 & 10.8 \\
\hline & 421 & $0.61^{\circ} \mathrm{W}$ & 25.0 & 11.5 & 19.5 & 56.0 \\
\hline & 422 & $0.68^{\circ} \mathrm{W}$ & 16.0 & 10.4 & 3.2 & 29.6 \\
\hline
\end{tabular}


570 Table 2: Average abundances and standard lengths ( $\pm 1 \mathrm{SD})$ for all species identified in the northern transect (a), the southern transect (b) and at

571 the 18h-station (c). Numbers are based on depth integrated GULF VII, except for species which were only found in MOCNESS hauls. These

572 species are denoted with asterisks.

a

\begin{tabular}{|c|c|c|c|c|c|c|c|c|c|c|}
\hline \multicolumn{3}{|c|}{ Taxon } & \multicolumn{3}{|c|}{$\begin{array}{c}\text { Abundance } \\
\left(\text { nos. } \mathrm{m}^{-2}\right)\end{array}$} & \multirow{2}{*}{\begin{tabular}{r}
\multicolumn{1}{c}{$\begin{array}{c}\text { nos. } \\
\text { caught }\end{array}$} \\
30
\end{tabular}} & \multirow{2}{*}{$\begin{array}{r}\begin{array}{c}\% \\
\text { measured }\end{array} \\
93.3\end{array}$} & \multicolumn{3}{|c|}{$\begin{array}{c}\text { Std. Length } \\
(\mathrm{mm})\end{array}$} \\
\hline \multirow[t]{20}{*}{$60.75^{\circ} \mathrm{N}$} & Clupeidae & Clupea harengus & 6.9 & \pm & 5.8 & & & 17.8 & \pm & 2.7 \\
\hline & Gadidae & Melanogrammus aeglefinus & 2.7 & \pm & 4.8 & 4 & 100.0 & 8.9 & \pm & 3.1 \\
\hline & & Merlangius merlangus & 22.4 & \pm & 40.4 & 27 & 100.0 & 7.4 & \pm & 1.4 \\
\hline & & Pollachius pollachius & 2.3 & \pm & 2.4 & 7 & 100.0 & 8.5 & \pm & 1.9 \\
\hline & & Pollachius virens & 8.5 & \pm & 11.6 & 14 & 100.0 & 9.7 & \pm & 2.9 \\
\hline & & Trisopterus esmarkii & 51.3 & \pm & 71.9 & 100 & 100.0 & 9.2 & \pm & 2.5 \\
\hline & & Trisopterus minutus & 7.0 & \pm & 14.7 & 8 & 100.0 & 8.4 & \pm & 1.0 \\
\hline & & Unidentified & 3.0 & \pm & 4.3 & 8 & 62.5 & 6.6 & \pm & 4.1 \\
\hline & Gobiidae & Gobiusculus flavescens & 3.3 & \pm & 7.4 & 3 & 100.0 & 6.9 & \pm & 1.6 \\
\hline & Lotidae & Ciliata septentrionalis & 2.4 & \pm & 4.9 & 3 & 100.0 & 5.4 & \pm & 1.0 \\
\hline & & Molva dipterygia & 1.1 & \pm & 2.5 & 1 & 100.0 & 6.5 & \pm & \\
\hline & & Molva molva & 6.7 & \pm & 14.9 & 6 & 100.0 & 5.2 & \pm & 0.6 \\
\hline & Pleuronectidae & Glyptocephalus cynoglossus & 2.5 & \pm & 4.8 & 3 & 100.0 & 9.7 & \pm & 1.0 \\
\hline & & Hippoglossoides platessoides & 6.0 & \pm & 9.7 & 10 & 100.0 & 8.6 & \pm & 1.8 \\
\hline & & Limanda limanda & 4.7 & \pm & 6.9 & 6 & 100.0 & 8.0 & \pm & 4.0 \\
\hline & & Pleuronectes platessa & 2.2 & \pm & 5.0 & 2 & 100.0 & 6.3 & \pm & 0.4 \\
\hline & & Unidentified & 0.7 & \pm & 1.1 & 3 & 66.7 & 7.8 & \pm & 1.1 \\
\hline & Scophthalmidae & Lepidorhombus whiffiagonis & 1.1 & \pm & 2.5 & 1 & 100.0 & 10.6 & \pm & \\
\hline & & Phrynorhombus norvegicus & 0.4 & \pm & 0.6 & 2 & 100.0 & 9.2 & \pm & 2.0 \\
\hline & & Scophthalmus rhombus & 3.6 & \pm & 7.3 & 4 & 100.0 & 4.9 & \pm & 1.5 \\
\hline
\end{tabular}


b

\begin{tabular}{|c|c|c|c|c|c|c|c|c|c|c|}
\hline \multicolumn{3}{|c|}{ Taxon } & \multicolumn{3}{|c|}{ 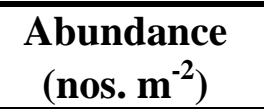 } & \multirow{2}{*}{$\begin{array}{r}\begin{array}{c}\text { nos. } \\
\text { caught }\end{array} \\
7\end{array}$} & \multirow{2}{*}{$\begin{array}{c}\begin{array}{c}\% \\
\text { measured }\end{array} \\
100.0\end{array}$} & \multicolumn{3}{|c|}{$\begin{array}{c}\text { Std. Length } \\
(\mathrm{mm})\end{array}$} \\
\hline \multirow[t]{17}{*}{$59.3^{\circ} \mathrm{N}$} & Ammodytidae & Ammodytes marinus & 3.1 & \pm & 6.9 & & & 16.2 & \pm & - \\
\hline & & Hyperoplus lanceolatus & 1.8 & \pm & 2.8 & 10 & 100.0 & 18.8 & \pm & 5.3 \\
\hline & & Unidentified & & \pm & 1.0 & 2 & 100.0 & 17.5 & \pm & 3.7 \\
\hline & Argentinidae & Argentina sphyraena & 0.4 & \pm & 1.0 & 1 & 100.0 & 10.0 & \pm & - \\
\hline & Clupeidae & Clupea harengus & 5.8 & \pm & 12.6 & 117 & 94.9 & 17.1 & \pm & 26.3 \\
\hline & Gadidae & Gadus morhua & 4.4 & \pm & 7.7 & 11 & 90.9 & 8.3 & \pm & 3.5 \\
\hline & & Melanogrammus aeglefinus & 7.6 & \pm & 9.8 & 22 & 100.0 & 9.7 & \pm & 5.0 \\
\hline & & Merlangius merlangus & 5.2 & \pm & 8.7 & 12 & 100.0 & 5.9 & \pm & 8.2 \\
\hline & & Pollachius pollachius & 3.1 & \pm & 4.8 & 8 & 100.0 & 9.6 & \pm & 6.7 \\
\hline & & Pollachius virens & 2.6 & \pm & 4.8 & 6 & 100.0 & 10.4 & \pm & 10.5 \\
\hline & & Trisopterus esmarkii & 60.9 & \pm & 79.9 & 159 & 96.2 & 8.8 & \pm & 5.0 \\
\hline & & Trisopterus minutus & 4.4 & \pm & 7.7 & 10 & 100.0 & 6.3 & \pm & 7.9 \\
\hline & & Unidentified & 2.2 & \pm & 3.8 & 5 & 20.0 & 9.2 & \pm & 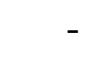 \\
\hline & Lotidae & Ciliata mustela & 0.9 & \pm & 2.0 & 2 & 100.0 & 5.1 & \pm & 0.2 \\
\hline & Pleuronectidae & Hippoglossoides platessoides & 4.6 & \pm & 5.6 & 14 & 100.0 & 11.2 & \pm & 3.1 \\
\hline & & Limanda limanda & 2.6 & \pm & 4.8 & 6 & 83.3 & 7.8 & \pm & 1.7 \\
\hline & Scophthalmidae & Scophthalmus rhombus & 0.9 & \pm & 2.0 & 2 & 100.0 & 3.8 & \pm & 0.3 \\
\hline
\end{tabular}


C

\begin{tabular}{|c|c|c|c|c|c|c|c|c|c|c|}
\hline \multirow{2}{*}{$\frac{\text { Transect }}{18 \mathrm{~h}-\text { St. }}$} & \multirow{2}{*}{$\begin{array}{c}\text { Family } \\
\text { Ammodytidae }\end{array}$} & axon & \multicolumn{3}{|c|}{$\begin{array}{l}\text { Abundance } \\
\left(\text { nos. } \mathbf{m}^{-2}\right)\end{array}$} & \multirow{2}{*}{$\begin{array}{r}\begin{array}{c}\text { nos. } \\
\text { caught }\end{array} \\
1\end{array}$} & \multirow{2}{*}{$\begin{array}{c}\begin{array}{c}\% \\
\text { measured }\end{array} \\
100.0\end{array}$} & \multicolumn{3}{|c|}{$\begin{array}{c}\text { Std. Length } \\
(\mathrm{mm})\end{array}$} \\
\hline & & Hyperoplus immaculatus* & 0.2 & \pm & 0.4 & & & 11.9 & \pm & $\overline{0}$ \\
\hline & & Hyperoplus lanceolatus & 0.8 & \pm & 1.8 & 1 & 100.0 & 40 & \pm & - \\
\hline & Argentinidae & Argentina sphyraena & 20.0 & \pm & 29.2 & 11 & 90.9 & 10.1 & \pm & 2.4 \\
\hline & Clupeidae & Clupea harengus & 0.5 & \pm & 1.1 & 1 & 100.0 & 14.9 & \pm & - \\
\hline & Gadidae & Gadus morhua & 1.3 & \pm & 2.8 & 1 & 100.0 & 5.8 & \pm & - \\
\hline & & Melanogrammus aeglefinus & 3.6 & \pm & 2.4 & 4 & 100.0 & 6.3 & \pm & 1.4 \\
\hline & & Merlangius merlangus & 152.3 & \pm & 138.5 & 113 & 99.1 & 6.3 & \pm & 1.3 \\
\hline & & Pollachius pollachius & 9.4 & \pm & 15.0 & 5 & 100.0 & 7.1 & \pm & 1.6 \\
\hline & & Pollachius virens & 15.3 & \pm & 8.5 & 13 & 100.0 & 7.0 & \pm & 2.4 \\
\hline & & Trisopterus esmarkii & 81.2 & \pm & 77.6 & 57 & 98.2 & 7.2 & \pm & 1.6 \\
\hline & & Trisopterus minutus & 7.4 & \pm & 7.6 & 5 & 80.0 & 6.2 & \pm & 1.4 \\
\hline & & Unidentified & 14.4 & \pm & 11.7 & 13 & 76.9 & 5.3 & \pm & 1.0 \\
\hline & Gobiidae & Gobius niger & 0.8 & \pm & 1.8 & 1 & 100.0 & 5.5 & \pm & \\
\hline & & Gobiusculus flavescens & 3.6 & \pm & 8.0 & 1 & 100.0 & 6.8 & \pm & \\
\hline & & Unidentified* & 0.2 & \pm & 0.4 & 1 & 100.0 & 2.7 & \pm & \\
\hline & Lotidae & Ciliata septentrionalis & 17.8 & \pm & 22.0 & 14 & 100.0 & 5.7 & \pm & 0.9 \\
\hline & & Molva dipterygia & 7.2 & \pm & 16.0 & 2 & 100.0 & 7.9 & \pm & 0.2 \\
\hline & & Molva molva & 2.5 & \pm & 5.7 & 2 & 100.0 & 6.9 & \pm & 0.8 \\
\hline & Pleuronectidae & Glyptocephalus cynoglossus & 6.2 & \pm & 6.9 & 4 & 100.0 & 6.9 & \pm & 1.3 \\
\hline & & Hippoglossoides platessoides & 20.2 & \pm & 29.2 & 12 & 83.3 & 8.3 & \pm & 3.3 \\
\hline & & Limanda limanda & 2.5 & \pm & 5.6 & 5 & 80.0 & 6.8 & \pm & 1.6 \\
\hline & & Platichthys flesus* & 0.4 & \pm & 0.9 & 5 & 100.0 & 3.5 & \pm & 0.5 \\
\hline & & Pleuronectes platessa & 0.8 & \pm & 1.8 & 1 & 100.0 & 10.4 & \pm & \\
\hline & & Unidentified & 1.3 & \pm & 1.9 & 2 & 100.0 & 5.3 & \pm & 0.5 \\
\hline & Scophthalmidae & Scophthalmus rhombus & 18.6 & \pm & 20.2 & 12 & 100.0 & 4.5 & \pm & 0.7 \\
\hline
\end{tabular}


577 Figure captions:

578 Figure 1: CTD, GULF VII and MOCNESS stations sampled during the survey. The aggregation of samples in the black rectangle represents the 18 hours station, containing 5 hauls with each gear in a 5 x 5 NM square.

581

582 Figure 2: Profiles of $\sigma_{\mathrm{t}}$, contoured for $0.1 \mathrm{~kg} \mathrm{~m}^{-3}$ (thin grey lines) and $0.5 \mathrm{~kg} \mathrm{~m}^{-3}$ (bold grey 583 lines) and abundance of fish larvae along the transects at $59.3^{\circ} \mathrm{N}$ (panel a) and $60.75^{\circ} \mathrm{N}$ (panel b). Only the most common species are given, while gadoids other than Norway pout and whiting, and flatfish other than long rough dab and brill are combined. Miscellaneous species comprised Clupeidae, Argentiniade, Ammodytidae, Lotidae and Gobidae which did not commonly occur.

Figure 3: Temperature, salinity and fluorescence at the 18h-station (panel a), averaged over all 5 hauls. The broken lines depict the boundaries between the sampled depth strata in depth discrete hauls. Most changes in hydrography and fluorescence occurred between 50 and 80 m, mainly in the stratum between 40 and $75 \mathrm{~m}$. Error bars are only shown for every ten metres of depth. Panels b and c show the distribution of all size classes of zooplankton $(<1000 \mu \mathrm{m}, 1000-2000 \mu \mathrm{m}$ and $>2000 \mu \mathrm{m})$ during daylight and night conditions in $\%$ of total.

Figure 4: Vertical distribution of gadoid fish larvae and $<1000 \mu \mathrm{m}$ zooplankton by dry 
599

600

601

602

603

604

605

606

607

608

609

610

611

612

613

614

615

616

617

618

619

620

of larvae caught under the respective light conditions (in subscript). The y-axis depicts the boundaries between sampled strata.

Figure 5: Vertical distribution of flatfish larvae and $<1000 \mu \mathrm{m}$ zooplankton dry weight, during day and night in \% of total abundance or biomass. $\mathrm{N}$ represents the number of larvae caught under the respective light conditions (in subscript). The y-axis depicts the boundaries between sampled strata.

Figure 6: Depth of the centre of abundance for gadoid (a) and flatfish larvae (b) in three different light environments. Due to the long days at this time of the year, there was only one station at dusk (21:52 UTC) and night (23:56 UTC), while three stations were in daylight (19:14 UTC, 06:20 UTC and 08:22 UTC). As it was shortly after sunrise the station at 06:20 UTC was not included into the calculation of $\mathrm{Z}_{\mathrm{cm}}$. The number of larvae caught under each light condition is given as $\mathrm{N}$ in the legend. The depth of mass for zooplankton (based on mg $\mathrm{m}^{-3}$ ) is depicted in both panels.

Figure 7: Depth of the centre of abundance for gadoid (a) and flatfish larvae (b) for individual samples taken at the 18h-station. Daylight stations were at 19:14 UTC, 06:20 UTC and 08:22 UTC, the station at 21:52 UTC was during dusk and the station at 23:56 UTC in the night. The number of larvae caught at each station is given as $\mathrm{N}$, with the time of sampling given in subscript. The depth of mass for zooplankton (based on $\mathrm{mg} \mathrm{m}^{-3}$ ) is depicted in both panels. 
622 Figure 8: Rounded length distribution across strata and light conditions of cod, haddock and

623

624

625

626

627

628

629

630

631

632

633

634

635

636

637

638

639

640

641

642

643

644

whiting as \% of total abundance. The majority of larvae ranged from 3 to $6 \mathrm{~mm}$ standard

length. Even for the larvae at the lower end of this range, changes in distribution across strata could change substantially between the different light conditions. Empty panels indicate zero findings for the respective species in this stratum, during the entire sampling period.

Figure 9: Rounded length distribution across strata and light conditions of saithe, pollock, Norway pout and poor cod in \% of total abundance. The majority of saithe and pollock were in a relatively narrow size range from 4 to $8 \mathrm{~mm} \mathrm{SL}$. Smaller larvae tended to aggregate at the 20 - 40 m stratum with increasing darkness. Larger larvae were distributed throughout the water column, but this is again based on few individuals. Norway pout covered a large size range (2 - $11 \mathrm{~mm})$ and, similar to saithe larvae $(4-6 \mathrm{~mm})$, tended to aggregate in the 20 - 40 m stratum with increasing darkness. During day and dusk conditions poor cod of all sizes were mostly found in the deeper strata. At night only a few large larvae in the $0-20 \mathrm{~m}$ stratum were found. Empty panels indicate zero findings for the respective species in this stratum, during the entire sampling period.

Figure 10: Rounded length distribution across strata and light conditions of witch, long rough dab and brill in \% of total abundance. Witch and long rough dab ranged mostly between 3 and $9 \mathrm{~mm}$ in standard length but with a few larvae in the extreme upper range of the size distribution which were found in the two strata between 20 and 75 m. The medium sized larvae were relatively dispersed during day and dusk and for witch appeared to aggregate in the uppermost stratum during the night. Brill was unique, as the majority of 
645 larvae were found at the low extreme of the size range and exhibited strong fluctuations 646 across the depth range.

647 
Figure 1:

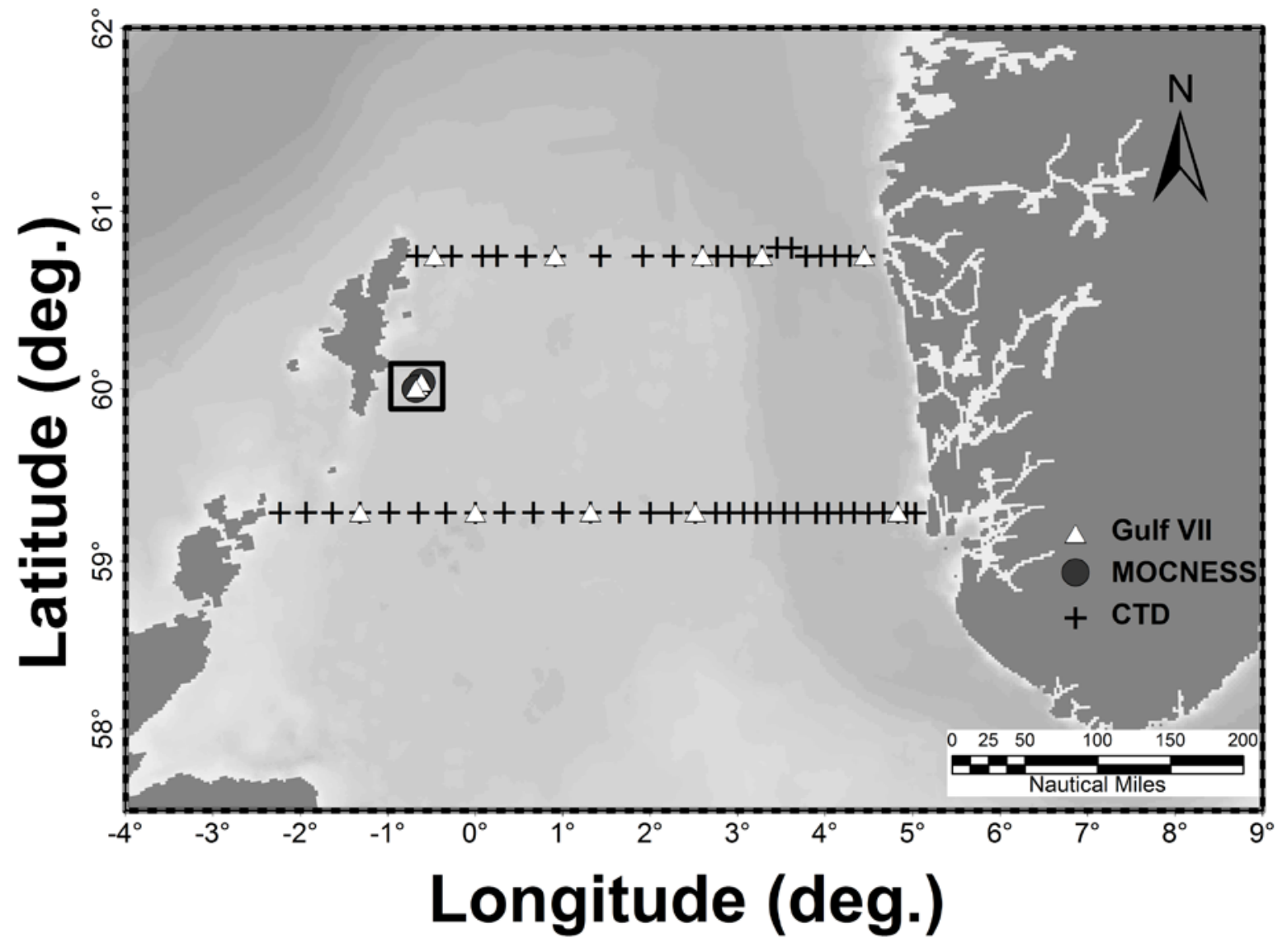


Figure 2:
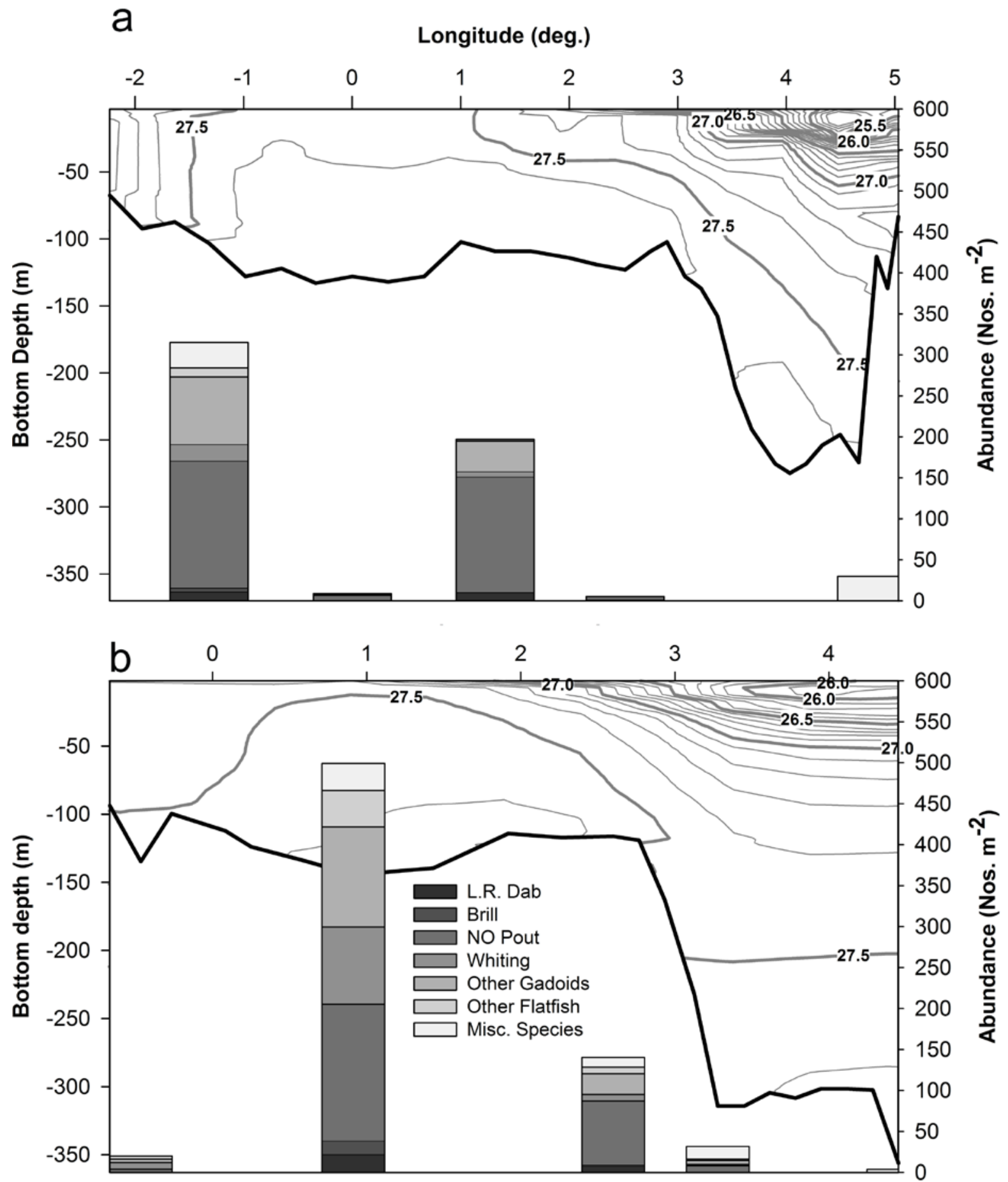
Figure 3:
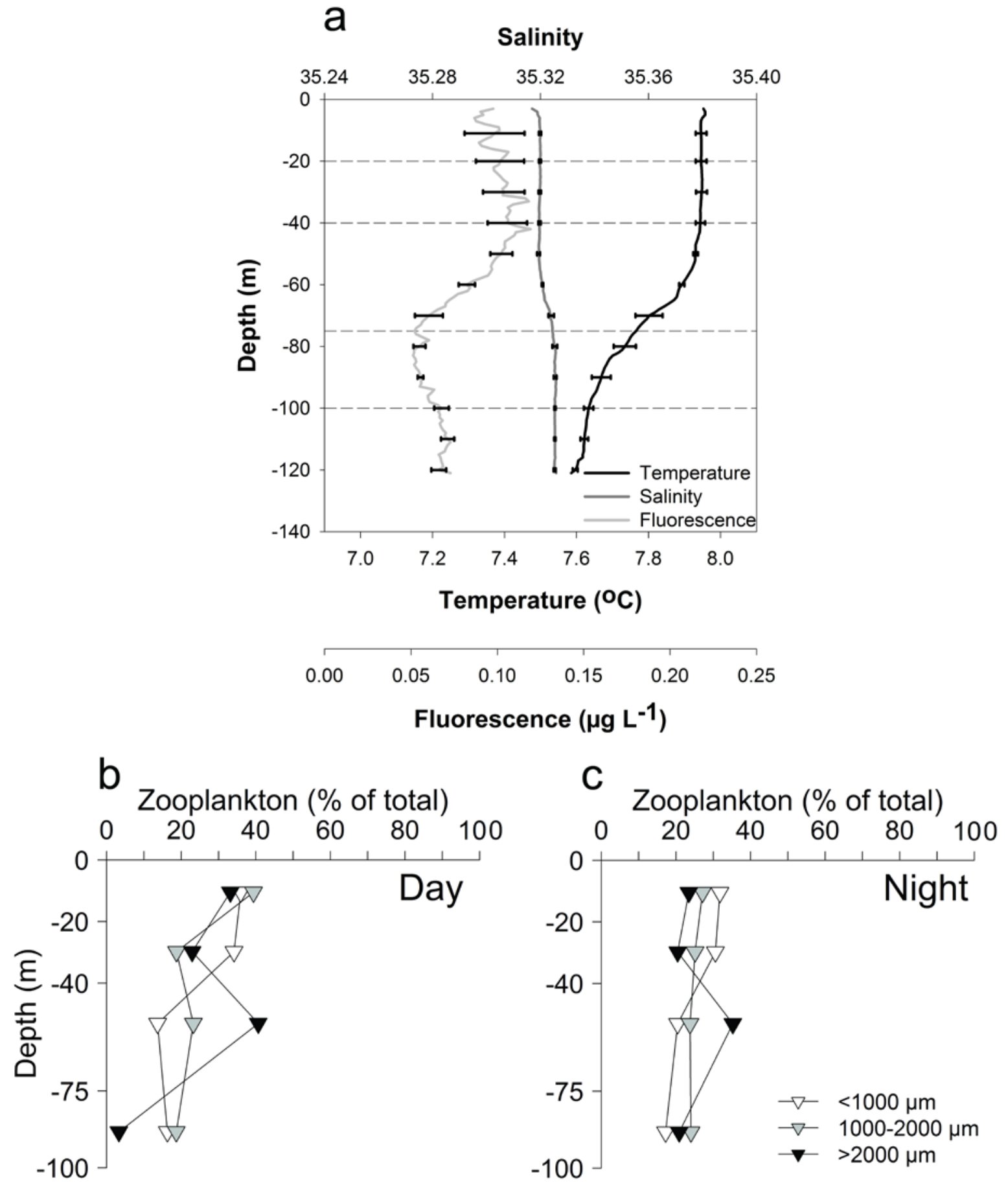
Figure 4:
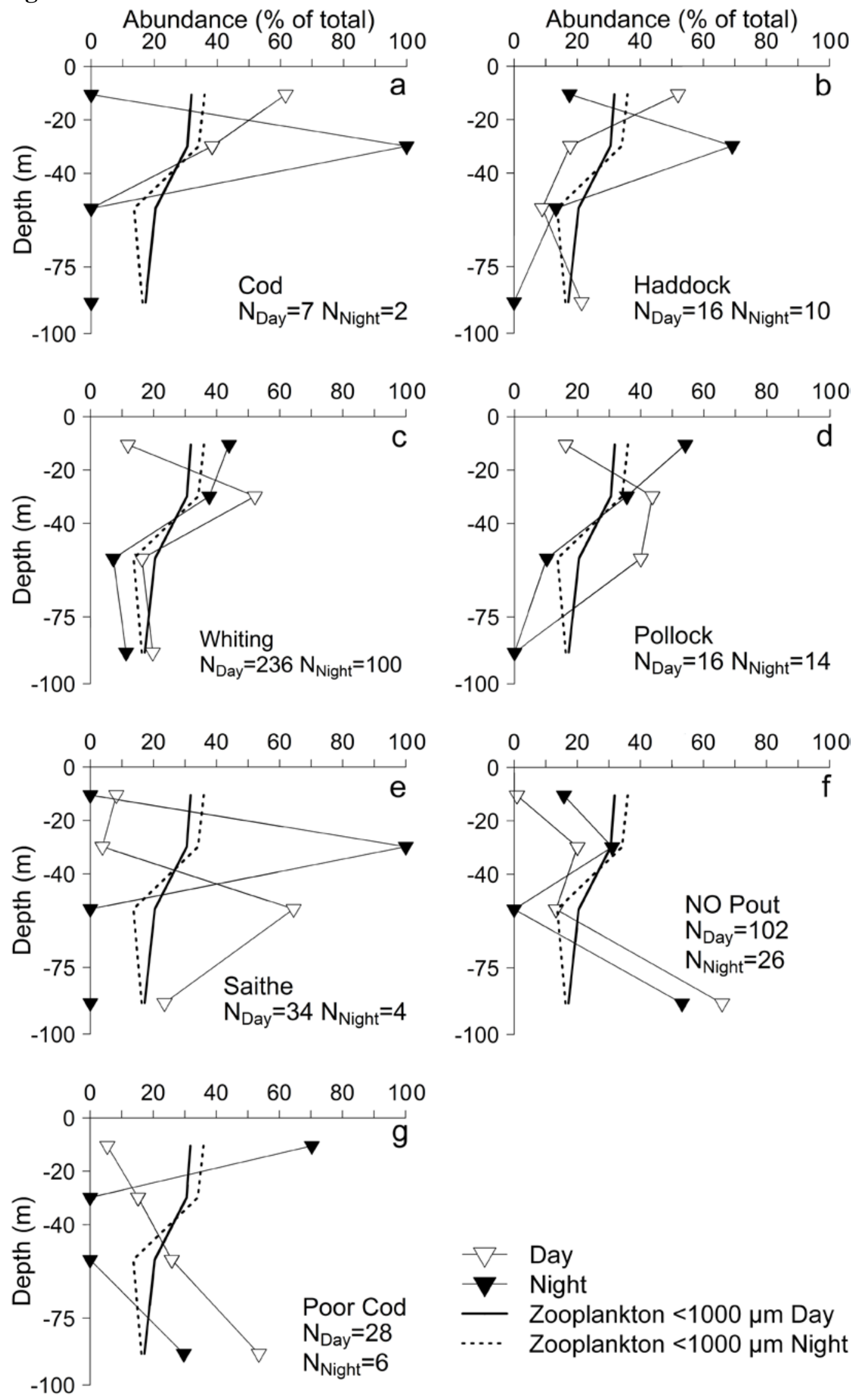
Figure 5:
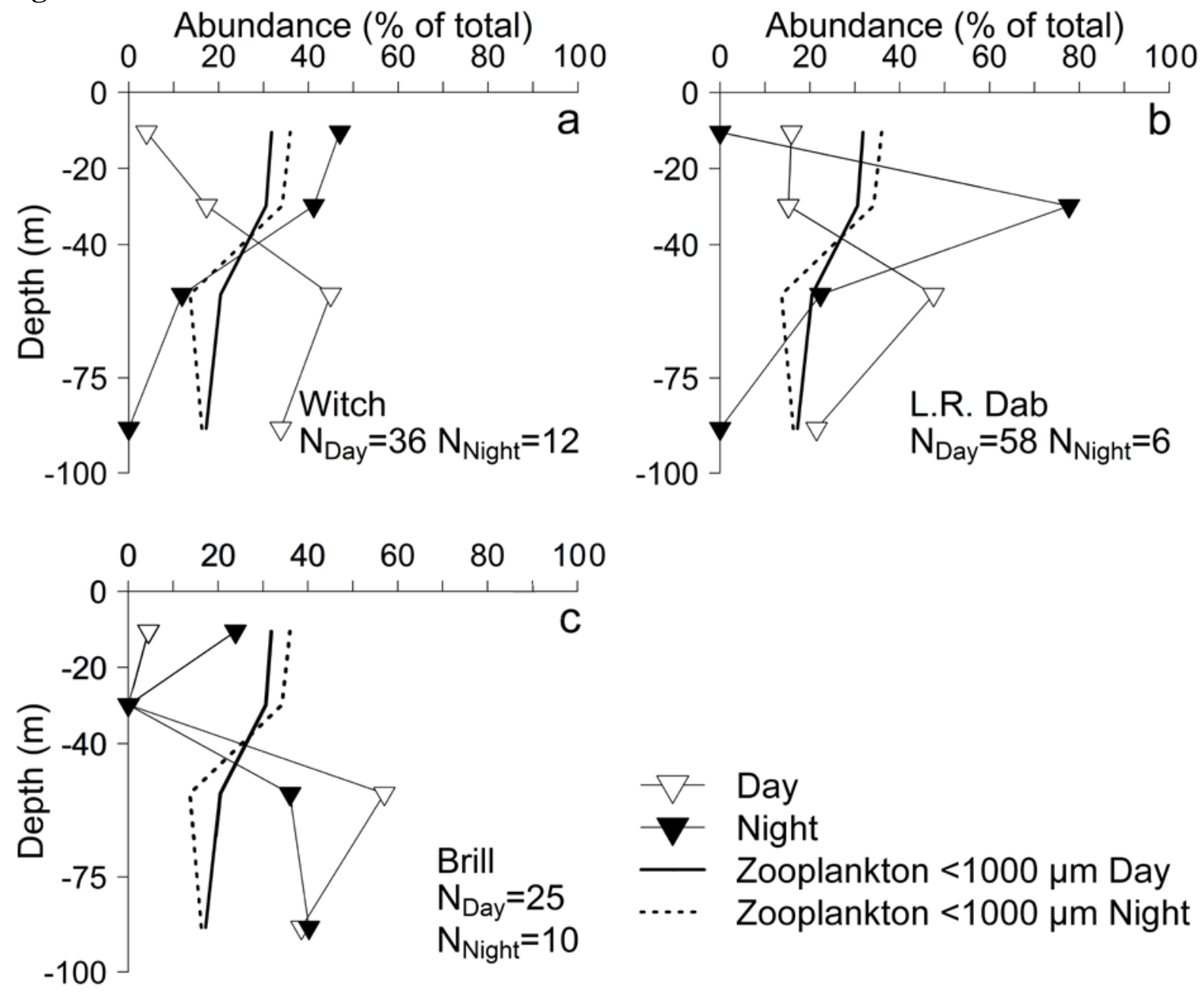
Figure 6:

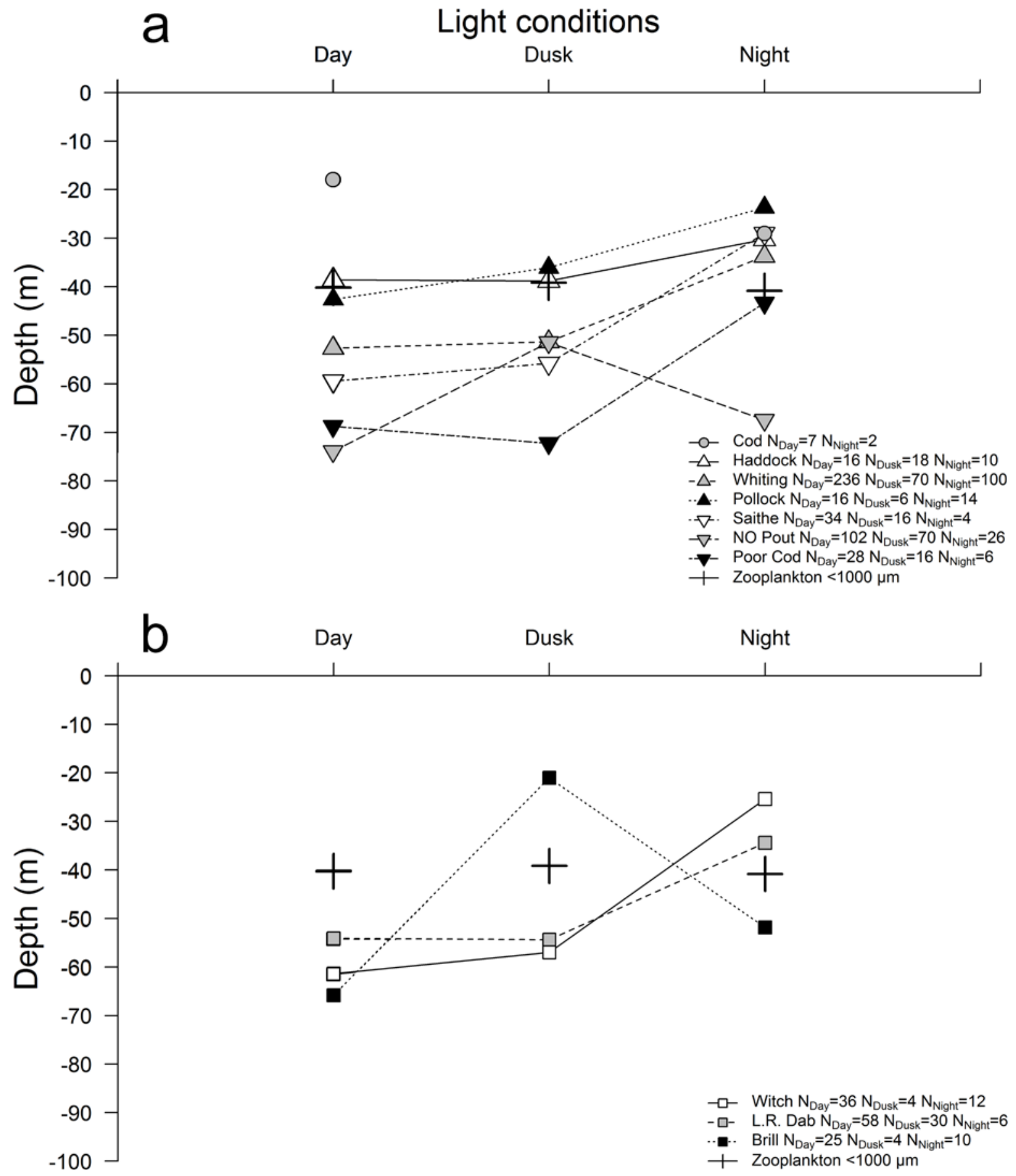


Figure 7:
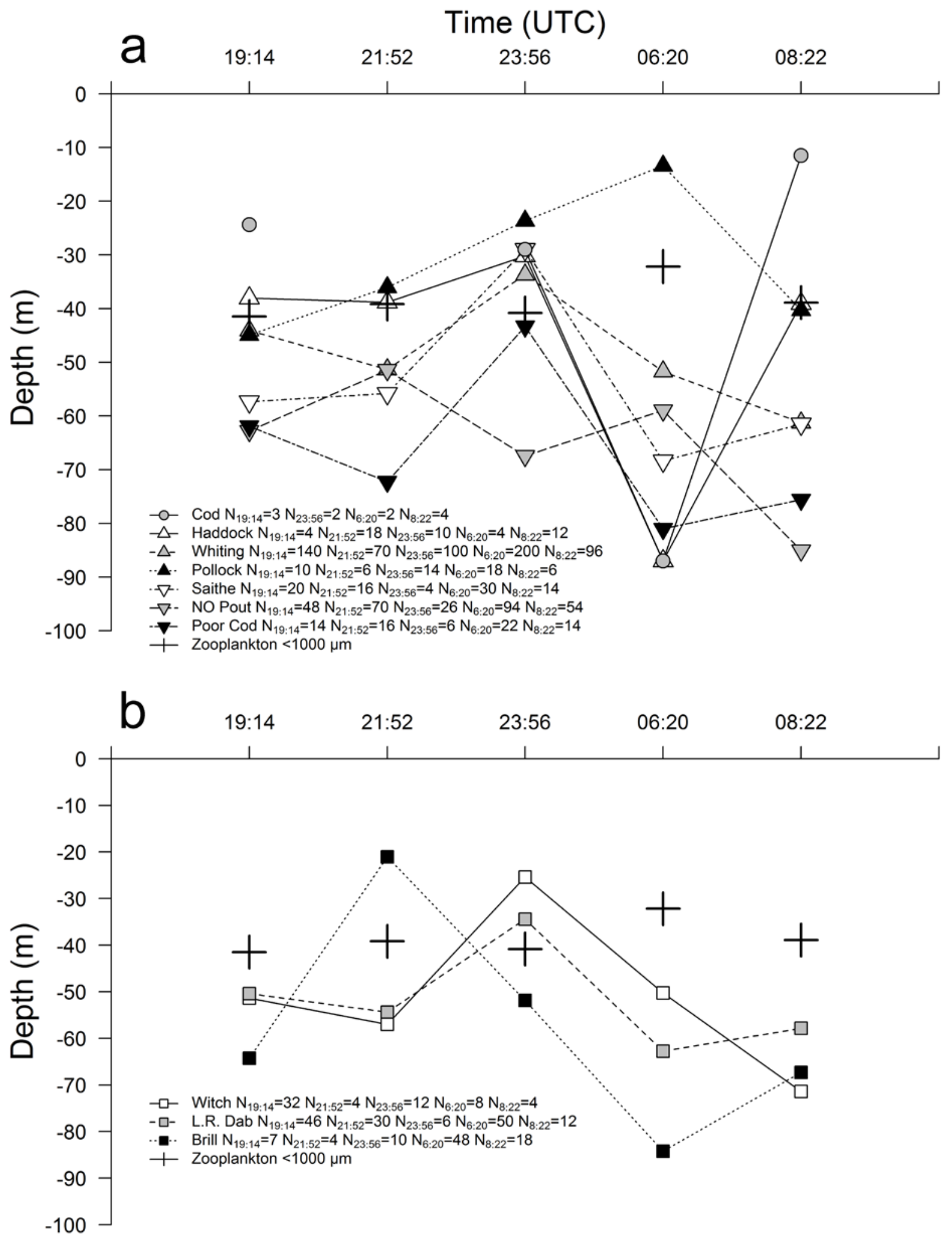
Figure 8:
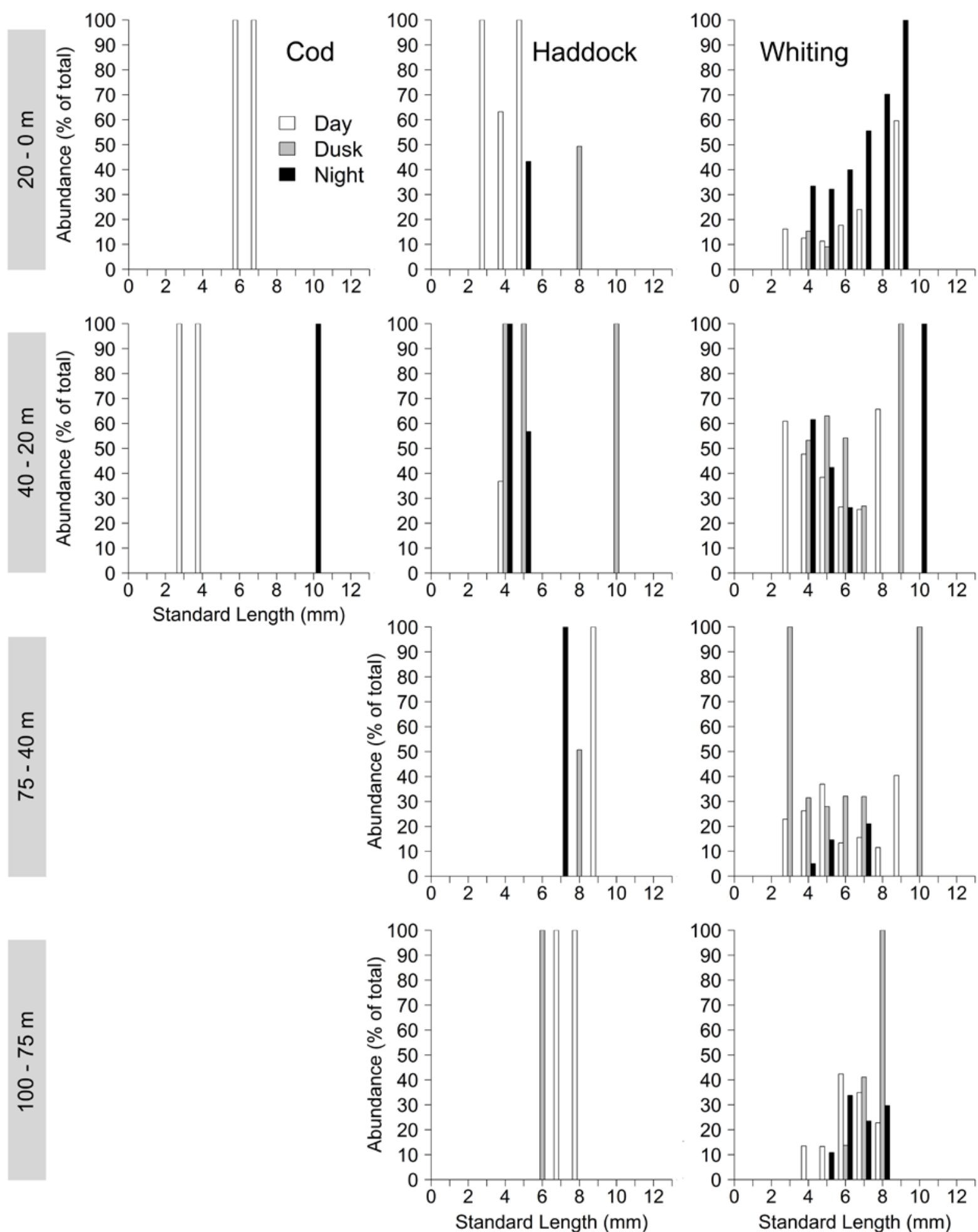
Figure 9:
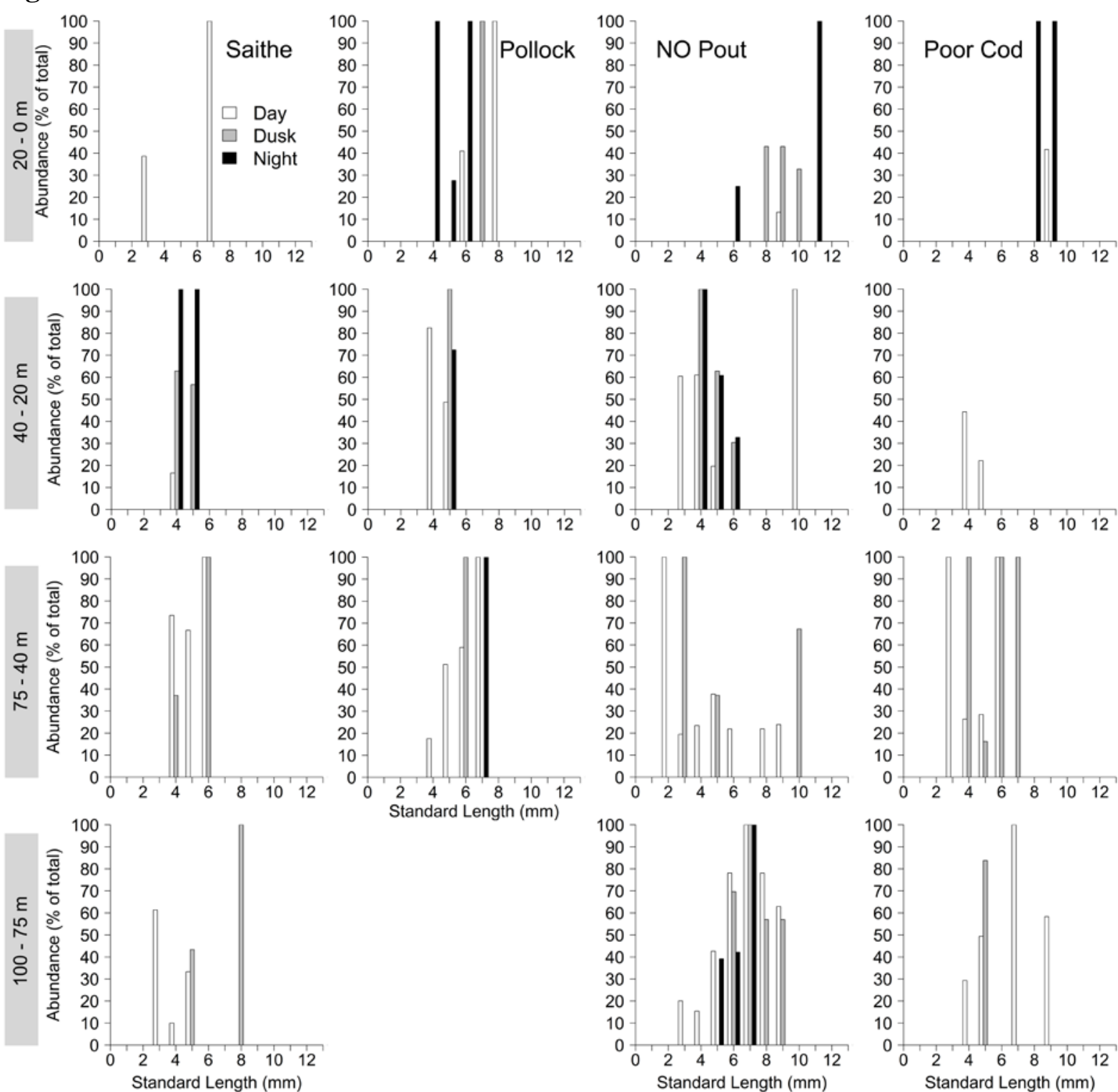
Figure 10:
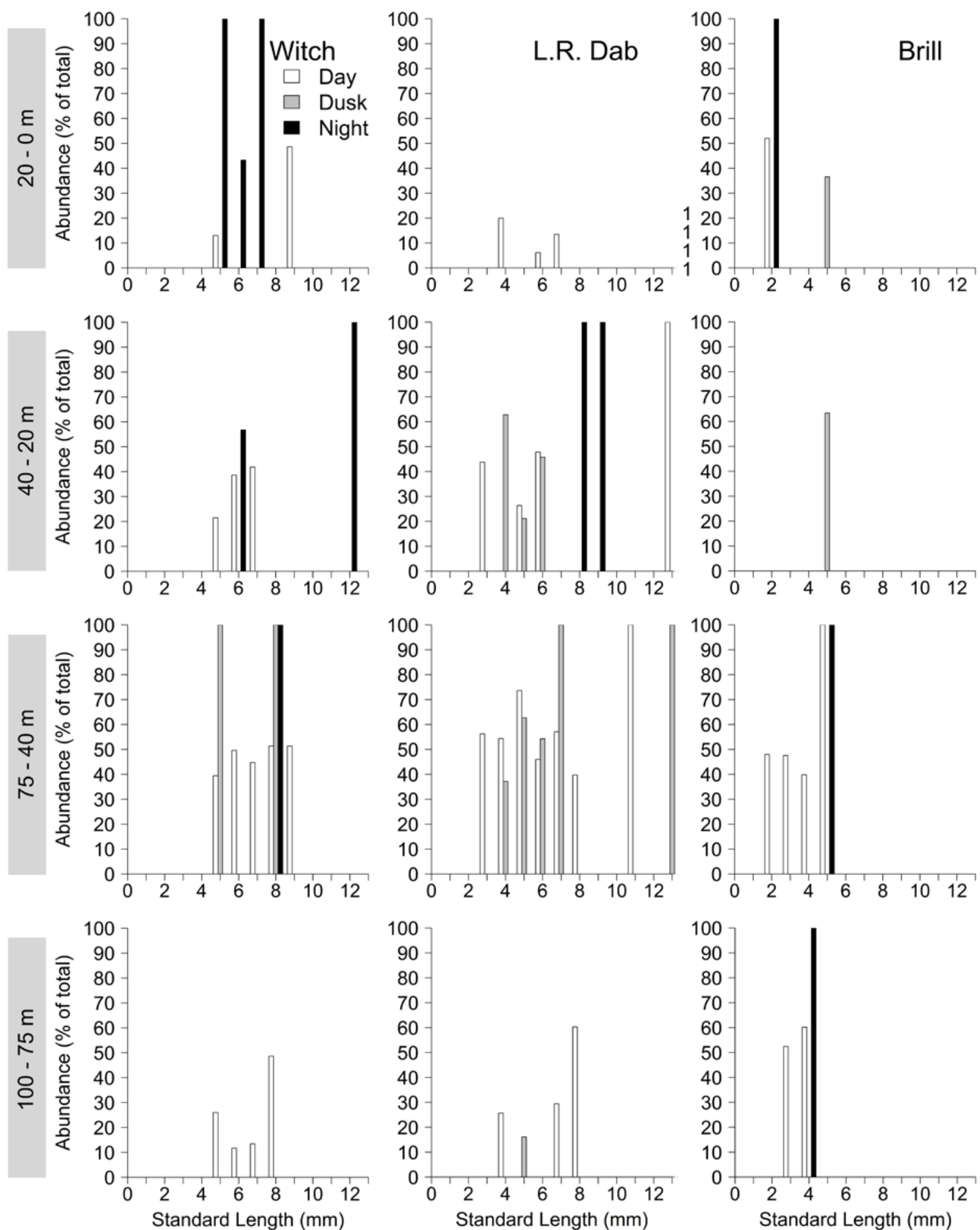